Article

\title{
Method of Stabilizing Heavily Spalted Big Leaf Maple as a Decorative Coating Veneer Layer for Engineered Wood Flooring
}

\author{
Diego Rodrigues de Oliveira $\mathbb{D}^{\mathbb{D}}$, Claudia C. Andersen, Sarath M. Vega Gutierrez $\mathbb{D}^{\mathbb{D}}$, \\ Frederick A. Kamke ${ }^{D}$ and Seri C. Robinson* \\ Wood Science \& Engineering, Oregon State University; Corvallis, OR 97331, USA; \\ diegorodrigues225@gmail.com (D.R.d.O.); claudia.c.andersen@gmail.com (C.C.A.); \\ Sarath.vega@oregonstate.edu (S.M.V.G.); fred.kamke@oregonstate.edu (F.A.K.) \\ * Correspondence: seri.robinson@oregonstate.edu
}

Received: 27 December 2018; Accepted: 13 February 2019; Published: 19 February 2019

check for updates

\begin{abstract}
Spalted wood, wood colored by fungi, has been popular in woodcraft for centuries. Most spalted wood, however, is found in an advanced state of decay and cannot be utilized. This project describes the use of viscoelastic thermal compression (VTC) to investigate the potential increase in spalted woods' strength and stiffness, with the main objective of converting so-called "punky" wood into the top layer (veneer layer or "coating") on commercial flooring. Spalted Acer macrophyllum logs were cut into veneers of size $7 \mathrm{~mm} \times 7.8 \mathrm{~cm} \times 25 \mathrm{~cm}$ and were then VTC-treated at $150{ }^{\circ} \mathrm{C}$ and 50 psi for $11.5 \mathrm{~min}$. Statistical analysis on the mixed linear models showed significant increases for both the density and hardness of spalted wood $(p<0.0001)$. Density and Brinell hardness increased by $84 \%$ and $209 \%$, respectively. FTIR analysis revealed that the wood polymers present in spalted wood were more susceptible to degradation imposed by the heat of the VTC treatment compared to sound wood. Additionally, the color analysis of the wood specimens showed statistically significant changes in color after the VTC treatment $(p<0.0001)$, which turned the wood surface darker and redder. The use of the VTC technology to transform spalted wood into wood flooring is viable. However, when exposed to moisture, the VTC-treated spalted wood showed a high percentage of set recovery $(78 \%)$, which was significantly different from the set recovery of the sound wood $(71 \%, p=0.004)$. Successful use of VTC-treated spalted wood for flooring will require addressing of the swelling issue, and additional studies are needed to fully characterize the anatomy of VTC-treated spalted wood.
\end{abstract}

Keywords: wood flooring; spalting; fungal pigments; stabilization

\section{Introduction}

Spalted wood (wood colored internally by fungi) is popular within U.S. woodworking and woodturning communities, although its use is mostly for inlay and woodturning [1,2]. The use of spalted wood in woodcraft began with early inlay techniques, which were popular in the early medieval era in Western Europe. Intarsia and marquetry panels were made by cutting small pieces of wood into different shapes, with thicknesses ranging from 3 to $5 \mathrm{~mm}$, from woods of different colors. These small pieces of wood were then inserted into carved recesses in a solid piece of wood to create a final image [3]. As there was no natural or synthetic colorant at the time that could produce a long-lasting blue-green color, blue-green spalted wood was frequently used, as was spalted wood with zone lines (thin, winding lines of melanin often found on spalted wood).

Historically and for much of the 20th century, spalted wood was gathered from forests for use [2,4], as it occurs mostly on dead trees, as the fungi responsible degrade cellulose, hemicellulose, and lignin. 
Due to the associated decay, spalted wood is often not suitable for load-bearing applications and is used primarily as an embellishment or decorative coating on sound wood. There have been a number of studies devoted to inducing spalting under laboratory conditions-hence minimizing the decay [5], but none of these studies have shown a method to produce spalted wood at a large-scale, commercial rate. Thus, spalted wood remains a market rarity despite its value $[1,2,5,6]$.

A great deal of spalted wood is available on forest floors, as decaying, dead wood, and represents a potential additional revenue stream for forest landowners. A sizable portion of this "free" wood is too far decayed even for craft and artwork, and is often left to rot [3]. Ideally, a method is needed that transforms so-called "punky" spalted wood (spalted wood that lacks rigidity due to advanced fungal degradation/spalted wood that is too unstable to use for any application) into a commercial product (in contrast to art, which is the usual venue for spalted wood). This would entail attempts to stabilize and increase the strength of the material, a subsection of spalting research that has been underway since 1982 [7].

Unfortunately, all current stabilization technologies for spalted wood are designed for small batch processing, use chemicals as stabilizers, and are aimed at the woodturner, not the lumber user [8]. A potential new technology that could produce stabilized boards without any additional chemical input would be the viscoelastic thermal compression (VTC) process, which compresses and densifies wood [9]. While this process has never before been tested on spalted wood, its results with other wood materials have shown significant improvement in the physical and mechanical properties of the wood, especially for low density wood species [9-12]. Therefore, the VTC process is an ideal process for stabilizing spalted big leaf maple (Acer macrophyllum Pursh.), which decays quickly once the tree is down (spalting is the first stage of decay) and is often left to rot on the forest floor.

This research aims to find a method to turn punky (overly decayed wood), spalted big leaf maple into the top veneer layer (the decorative coating layer) of engineered flooring with the use of viscoelastic thermal compression (VTC) - primarily for decorative purposes. This method uses heat, steam, and compression to increase the mechanical properties of spalted wood. Finding a fast, easily repeatable method for stabilizing punky, spalted wood could revolutionize the commercial nature of the material for woodworking, especially in applications such as cabinetry and flooring, making it economically viable to produce in large quantities for the first time, as well as increase revenue to forest landowners, both big and small, with wood that would otherwise be worthless.

\section{Materials and Methods}

Spalted Acer macrophyllum was collected from the McDonald-Dunn Research Forest. The forest consists of approximately 11,250 acres of predominantly forested land in Townships 10 and 11 South, and Range 5 West, Willamette Meridian, in Oregon, USA. Wood was selected based on the "fingernail" test, in which a fingernail is pressed into the end grain of the log [13]. If the fingernail sank into the wood, the wood was considered "punky" and appropriate for the test. If the fingernail did not sink in, the wood was considered too sound and was left behind. Only logs showcasing zone lines were collected. Forty-five logs averaging approximately $46 \mathrm{~cm}$ in length and $20 \mathrm{~cm}$ in diameter were used. Logs were from trunks, not branches.

The logs were cut into veneer sheets using a band saw, and then cut and sanded to final dimensions of $7 \mathrm{~mm} \times 7.8 \mathrm{~cm} \times 25 \mathrm{~cm}$. Ring orientation was not taken into account. There were a total of 150 spalted wood samples and 150 sound wood samples. After sanding but before treatment, the sheets were stored in a climate controlled room $\left(20^{\circ} \mathrm{C}, 65 \%\right.$ relative humidity) until the equilibrium moisture content of approximately $12 \%$ was achieved.

\subsection{Specimen Selection}

The classification of the spalted wood specimens was done based on the zone lines present on the surface of the specimen. An acetate template the same size of the specimens was divided in 120 squares, Figure 1, and used to sort the wood. If any zone lines were present in $40 \%$ or more of the squares, 
the specimen was used; otherwise, the sample was discarded. The variability among the specimens was high, so the selection of the specimens tried to minimize the impacts of this high variability of spalted wood in the final results.

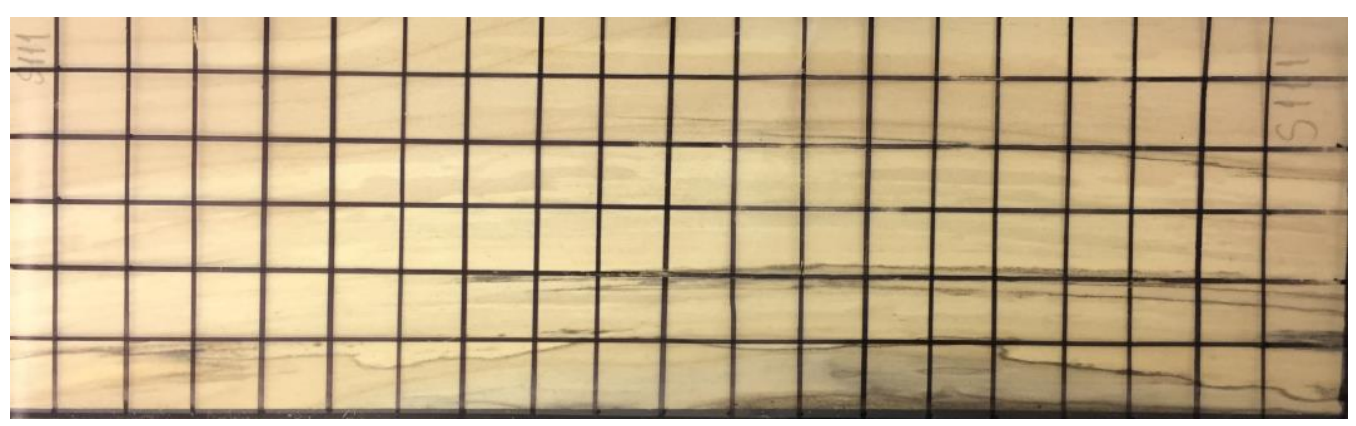

Figure 1. Acetate template on the surface of the wood specimen used to sort spalted wood samples.

\subsection{The VTC Process}

The viscoelastic thermal compression (VTC) was performed in the Green Building Materials Laboratory (GBML) at Oregon State University, Corvallis, OR, USA. The VTC machine is a pressurized vessel that is equipped with a heated hydraulic press (Figure 2).

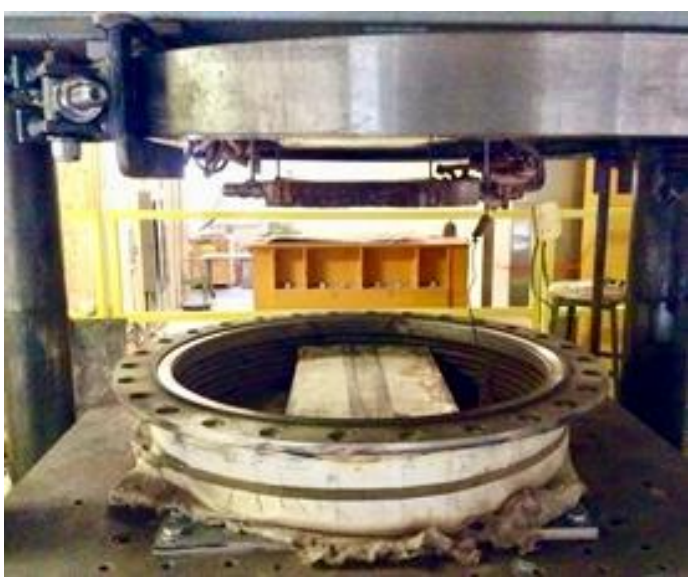

(a)

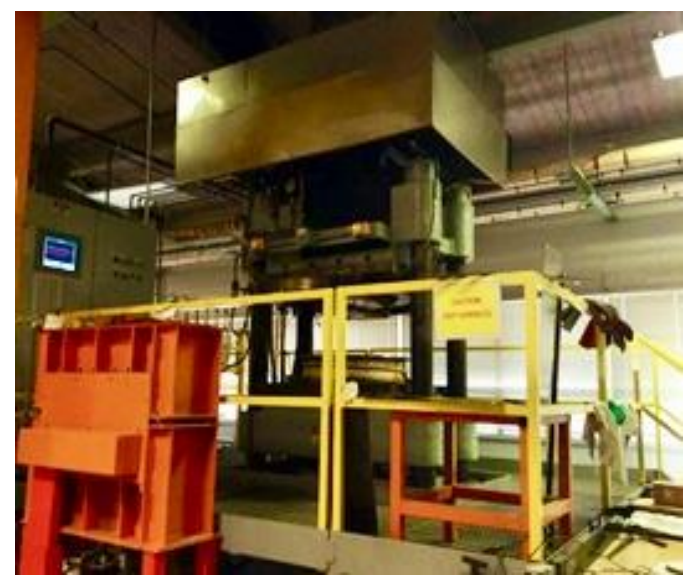

(b)

Figure 2. (a) Viscoelastic thermal compression (VTC) machine; (b) top and bottom plates of the machine.

Previous studies and pre-tests using the VTC process showed that spalted wood could be treated optimally at $150^{\circ} \mathrm{C}[14,15]$. While a higher temperature may achieve a more stable product, a higher temperature would also cause a darker color. Therefore, the temperature tested was $150^{\circ} \mathrm{C}$. The VTC process was divided into five phases: heating the wood samples to $150{ }^{\circ} \mathrm{C}$ for $35 \mathrm{~s}$; injecting steam inside the chamber at 50 psi for $180 \mathrm{~s}$; venting inside the chamber to remove excess of steam for $30 \mathrm{~s}$; compressing the wood samples for $190 \mathrm{~s}$; and cooling for $255 \mathrm{~s}$. The total time of the VTC process was $690 \mathrm{~s}$ (11.5 min). All the specimens were compressed to the same thickness, and the target thickness was $50 \%$ of the initial thickness of the wood specimens. The compression force varied depending on the resistance to compression.

Fifteen spalted wood samples and 15 sound wood samples were surface-treated using the VTC machine. The weight and dimensions of the samples were measured before and right after the treatment to calculate the density of the specimen pre- and post-treatment. The VTC-treated samples were then stored in a temperature controlled room $\left(20^{\circ} \mathrm{C}, 65 \%\right.$ relative humidity) for further tests. 


\subsection{Color Test}

Before performing the VTC treatment, the base color of each board was read in three locations on a Konika Minolta CR-5 color reader (Tokyo, Japan), as shown in Figure 3. The procedure was repeated for the 15 spalted wood samples and 15 sound wood samples. $\Delta E 2000$ values were calculated with the following formula:

$$
\Delta E *=\sqrt{\left(\frac{\Delta L^{\prime}}{k_{L} S_{L}}\right)^{2}+\left(\frac{\Delta C^{\prime}}{k_{C} S_{C}}\right)^{2}+\left(\frac{\Delta H^{\prime}}{k_{H} S_{H}}\right)^{2}+R_{T} \frac{\Delta C^{\prime}}{k_{C} S_{C}} \frac{\Delta H^{\prime}}{k_{H} S_{H}}}
$$

where $\Delta E$ is the overall color change, $\Delta L$ is the change in the $L$ value, $\Delta C$ is a combination of the change in $\Delta a$ and $\Delta b$ (without $L$ ), and $\Delta H$ is the change in hue. $R_{T}$ is a hue rotation term, and the various $\mathrm{K}$ terms are dependent upon the application. $S_{L}$ accounts for lightness, $S_{C}$ accounts for chroma, and $S_{H}$ accounts for hue.

The measurements were taken by using the original $L^{*} a^{*} b^{*}$ values as the control, and the ones after the execution of the VTC treatment the final $L^{*} a^{*} b^{*}$ values were taken again.

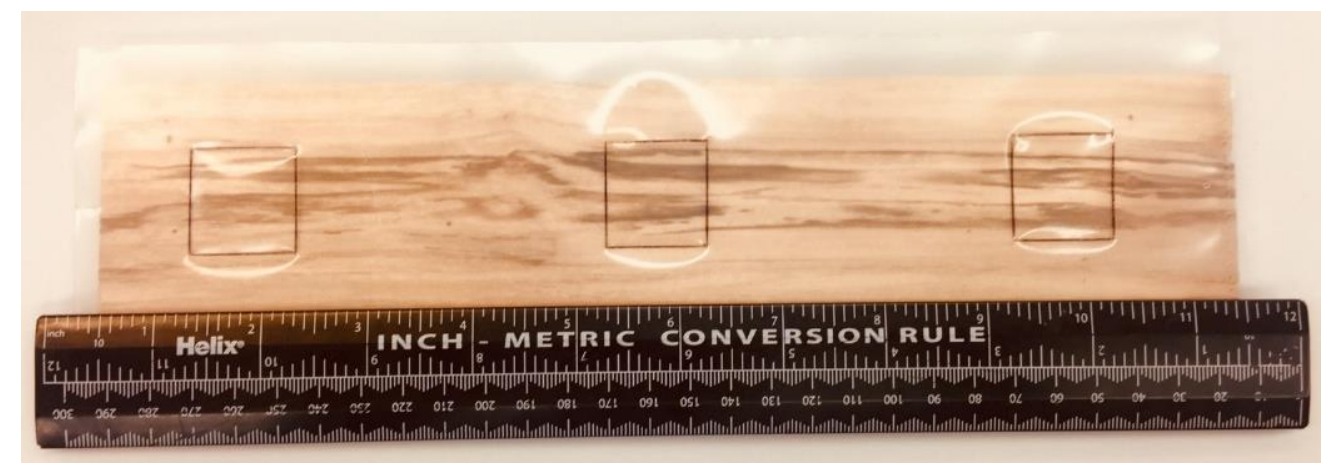

Figure 3. Sample showing the three color reading locations.

\subsection{Hardness Test}

The Brinell hardness (HB) test was conducted according to the European Standard-EN 1534 (2000) [16]. To perform the hardness test, the VTC-treated specimens with an original length of $25 \mathrm{~cm}$ were cut to a new length of $15 \mathrm{~cm}$. These 15 spalted wood samples and 15 sound wood samples were the samples used to determine the hardness after the VTC process. Because the hardness test is a destructive test, 15 new spalted wood samples and 15 sound wood samples of $7 \mathrm{~mm} \times 7.8 \mathrm{~cm} \times 15 \mathrm{~cm}$ were made to determine the hardness before the VTC treatment.

The hardness test was conducted using a universal testing machine (Sintech 1G, Sintech Scientific, Singapore) using $100 \mathrm{~kg}$ of force. The indentation depth and diameter of the area of the surface caused by the indenter was measured and the Brinell hardness in $\mathrm{N} / \mathrm{mm}^{2}$ was calculated according to the equations in EN 1534 (2000) [16].

\subsection{Set Recovery Test}

After the VTC process, 15 spalted wood and 15 sound wood samples $(7.5 \mathrm{~cm}$ in length) were cut from the original samples to determine the set recovery of the VTC specimens.

To do this, the samples underwent five cycles of drying and soaking in water. Each cycle consisted of first oven drying the specimens to $0 \%$ moisture content at $103{ }^{\circ} \mathrm{C}$ for $24 \mathrm{~h}$ and then soaking the specimens in water for $24 \mathrm{~h}$. The oven dry and soaking thickness were measured and after completing the cycles the percentage of set recovery was determined according to Laine et al. (2013) [17] using Equation (2):

$$
\text { Set recovery }=[(t s-t c) /(t i-t c)] \times 100(\%)
$$


where ts represents the oven-dry thickness after soaking the specimens, tc is the oven-dry compressed thickness, and $t i$ is the initial uncompressed thickness of the specimens.

\subsection{FTIR Test}

Fourier-transform infrared (FTIR) spectra of the wood specimens were recorded between 4000 and $550 \mathrm{~cm}^{-1}$ with a Nicolet iS50 FT-IR Spectrometer (Thermo Scientific, Waltham, MA, USA). The spectra were collected at a $4 \mathrm{~cm}^{-1}$ resolution by co-adding 64 scans and were displayed in absorbance.

For the FTIR analyses, slices from the 15 spalted wood samples and 15 sound wood samples before the VTC treatment were cut using a razor blade. The 30 samples were then VTC-treated, and new slices from each specimen were then cut for the FTIR. The visual data were collected and processed using the OMNIC Spectra Software (OMNIC Series Software 8.0).

\section{Data Analysis}

The statistical analyses were conducted using $\mathrm{R}$ version 3.4.3. For density, hardness, and color tests, an F-test was run for spalted and sound wood:

Density $=$ Wood I Treatment

Hardness $=$ Wood I Treatment

Color $=$ Wood I Treatment

Density was the calculated as the density of the wood in $\mathrm{kg} / \mathrm{m}^{3}$. Hardness was the calculated hardness of the wood in N/mm². Color was calculated by the SpectraMagic NX CMS-S100w 2.33.0004 software used to run the Konica Minolta Chroma Meter CR-5, which uses the CIE $L^{*} a^{*} b^{*}$ color space. Wood was the wood type (spalted or sound wood), and treatment was the VTC. Differences in density, hardness, and color between spalted and control groups showed a statistically significant change after VTC treatment.

For the set recovery test, a $t$-test was run for spalted and sound wood on the model:

$$
\text { Set recovery }=\text { Wood I Treatment }
$$

Set recovery was the calculated recovery of the original thickness of the wood specimens in a percentage. Difference in set recovery between spalted and sound wood post-VTC treatment did not indicate a statistical significant change in set recovery of VTC-treated spalted and sound wood.

For the FTIR, a quantitative analysis, was performed on the model:

$$
\text { FTIR }=\text { Wood I Treatment }
$$

where FTIR was the overall change in the chemistry of the wood given in graph formats by the OMNIC Spectra software used to run the Nicolet iS50 FT-IR Spectrometer (Thermo Scientific, Waltham, MA, USA).

\section{Results}

\subsection{Density}

The VTC process increased the density of spalted wood on average from 472 to $868 \mathrm{~kg} / \mathrm{m}^{3}$, where the density of the sound wood was increased from 562 to $1070 \mathrm{~kg} / \mathrm{m}^{3}$ on average. Table 1 shows the average density values, standard deviations, and coefficient of variation for spalted and sound wood before and after treatment. 
Table 1. Average density, standard deviation, and coefficient of variation (CV) from the raw data $(n=15)$ of viscoelastic thermal compression (VTC)-treated and untreated spalted and sound wood specimens.

\begin{tabular}{ccccc}
\hline Type of Wood & VTC Treatment & Density $\left(\mathbf{k g} / \mathbf{m}^{\mathbf{3}}\right)$ & Standard Deviation & CV (\%) \\
\hline \multirow{2}{*}{ Spalted wood } & before & 472 & 50 & 11 \\
\cline { 2 - 5 } & after & 868 & 77 & 9 \\
\hline \multirow{2}{*}{ Sound wood } & before & 562 & 30 & 5 \\
\cline { 2 - 5 } & after & 1070 & 28 & 2 \\
\hline
\end{tabular}

The statistical analysis on the mixed linear model using an F-test showed statistically significant differences between the densities before and after the VTC treatment considering the treatment effects for both wood types: spalted and sound $\left(\mathrm{F}_{1,28}=80, p<0.0001\right)$. The box plot, Figure 4 , shows the estimated differences in the mean densities of spalted and sound wood before and after the VTC treatment.

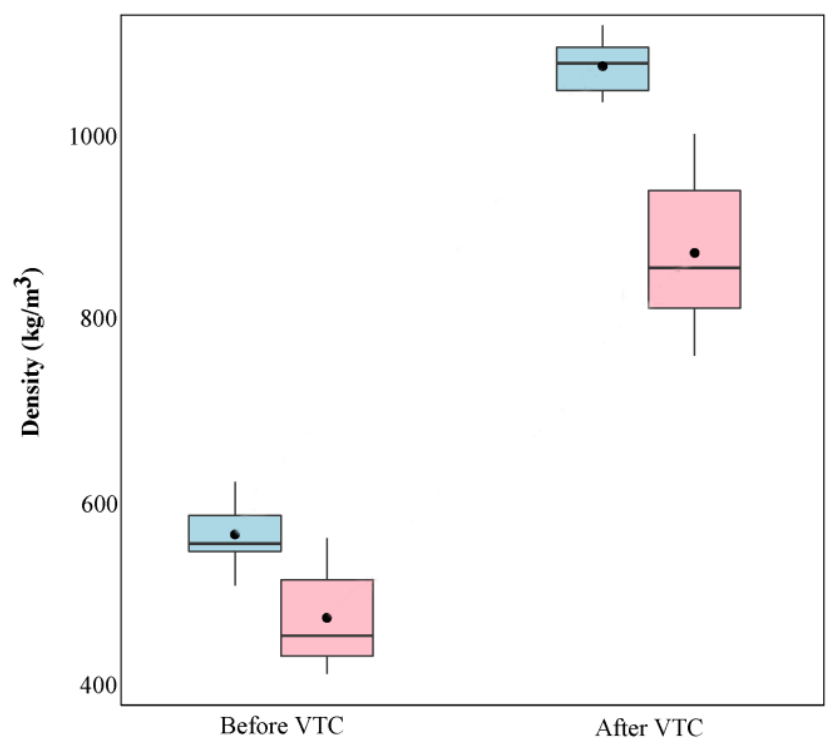

Figure 4. Differences in the mean densities of spalted (pink) and sound (blue) wood before and after the VTC treatment.

The densities between spalted and sound wood samples were compared before and after performing the VTC treatment. A test of interaction showed a statistical difference among all four group samples $\left(\mathrm{F}_{1,28}=2835, p<0.0001\right)$. Further comparisons also showed strong statistical evidence that the difference in mean density between the sound and spalted wood samples before and after VTC treatment was different $\left(\mathrm{F}_{1,28}=43, p<0.0001\right)$. The VTC process caused higher densification in the sound wood samples compared to the spalted wood samples.

\subsection{Color Test}

The results of the color test are presented in Table 2. Both spalted and sound wood darkened after the VTC process $\left(\mathrm{F}_{1,28}=1743, p<0.0001\right)$. The treatment also caused statistically signficant changes in mean $a^{*}$ (specimen became more red: $\mathrm{F}_{1,28}=253, p<0.0001$ ). Mean $b^{*}$ values did not significantly change. 
Table 2. Average $L^{*} a^{*} b^{*}$, standard deviation in parenthesis, and coefficient of variation (CV) from the raw data $(n=15)$ of VTC-treated and untreated spalted and sound wood specimens.

\begin{tabular}{cccccccc}
\hline Wood Type & VTC Treatment & $\boldsymbol{L}^{*}$ & $\mathbf{C V ~ ( \% )}$ & $\boldsymbol{a}^{*}$ & $\mathbf{C V ~ ( \% )}$ & $\boldsymbol{b}^{*}$ & CV (\%) \\
\hline \multirow{2}{*}{$\begin{array}{c}\text { Spalted } \\
\text { wood }\end{array}$} & Before & $74(2)$ & 3 & $6(1)$ & 16 & $20(2)$ & 7 \\
\cline { 2 - 7 } & After & $67(3)$ & 4 & $7(1)$ & 13 & $20(1)$ & 7 \\
\hline \multirow{2}{*}{\begin{tabular}{c} 
Sound wood \\
\cline { 2 - 8 }
\end{tabular}} & Before & $75(1)$ & 2 & $8(1)$ & 10 & $19(1)$ & 4 \\
\hline
\end{tabular}

\subsection{Hardness Test}

Post-VTC treatment, the average hardness increased by $209 \%$ for spalted wood and $105 \%$ for sound wood. A statistical analysis of the Brinell hardness test values confirmed that the VTC process statistically significantly improved the hardness of both spalted and sound wood $\left(\mathrm{F}_{1,28}=630\right.$, $p<0.0001$ ). Table 3 shows the Brinell hardness values for VTC-treated and untreated wood specimens, and Figure 5 shows the estimated difference in the mean hardness of spalted and sound wood before and after the VTC treatment.

Table 3. Average Brinell hardness, standard deviation, and coefficient of variation (CV) from the raw data $(n=15)$ of VTC-treated and untreated spalted and sound wood specimens.

\begin{tabular}{ccccc}
\hline Type of Wood & $\begin{array}{c}\text { VTC } \\
\text { Treatment }\end{array}$ & $\begin{array}{c}\text { Hardness } \\
\mathbf{( N / \mathbf { m m } ^ { 2 } )}\end{array}$ & $\begin{array}{c}\text { Standard } \\
\text { Deviation }\end{array}$ & CV (\%) \\
\hline \multirow{2}{*}{ Spalted wood } & Before & 19 & 3 & 16 \\
\cline { 2 - 5 } & After & 59 & 9 & 15 \\
\hline \multirow{2}{*}{ Sound wood } & Before & 25 & 3 & 12 \\
\cline { 2 - 5 } & After & 52 & 3 & 6 \\
\hline
\end{tabular}

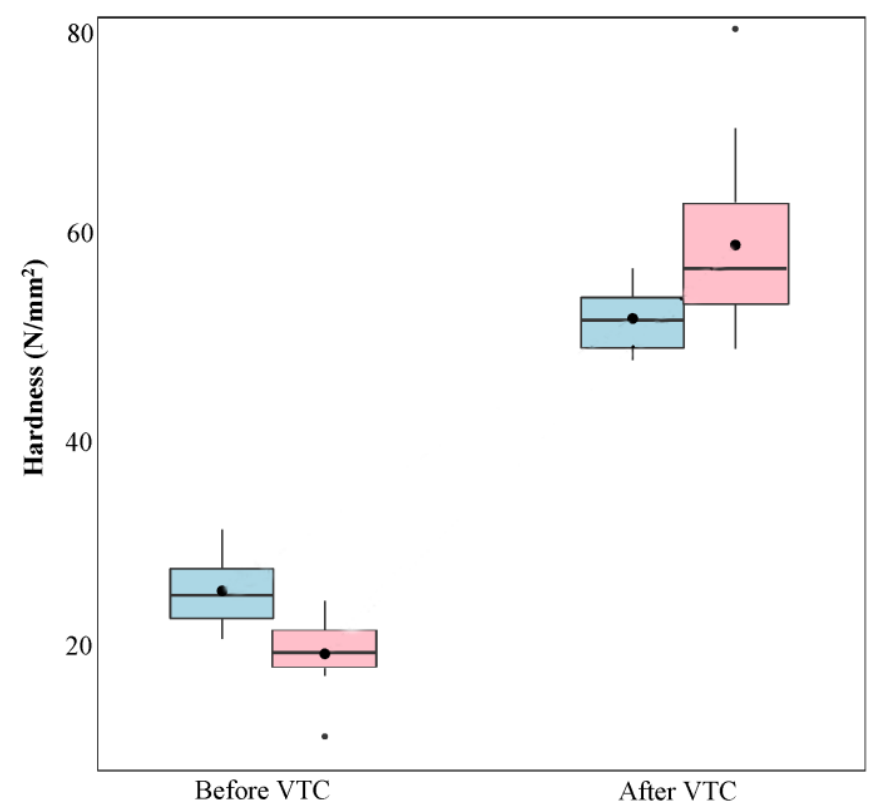

Figure 5. Differences in the mean Brinell hardness of spalted (pink) and sound (blue) wood before and after the VTC treatment.

The mean Brinell hardness of untreated spalted and sound wood were compared, and an F-test confirmed that there were no statistically significant differences between hardness for these two groups. In addition, the same analysis was done to compare the mean hardness of spalted samples to the 
sound wood samples post-VTC treatment, and no statistically significant differences were found $\left(\mathrm{F}_{1,28}=0.2, p=0.7\right)$.

\subsection{Set Recovery Test}

Statistical analysis using a $t$-test showed that the set recovery after the 5th cycle of soaking in water for $24 \mathrm{~h}$ and drying at $103^{\circ} \mathrm{C}$ for $24 \mathrm{~h}$ was statistically significantly higher for spalted wood than sound wood $(t(28)=3, p=0.004)$. Table 4 shows the average set recovery in percentage and standard deviations for spalted and sound wood after VTC treatment.

Table 4. Set recovery, standard deviation, and coefficient of variation (CV) from the raw data $(n=15)$ of VTC-treated spalted and sound wood specimens.

\begin{tabular}{cccc}
\hline Type of Wood & Set Recovery (\%) & Standard Deviation & CV (\%) \\
\hline Spalted wood & 78 & 7 & 8 \\
\hline Sound wood & 71 & 5 & 7 \\
\hline
\end{tabular}

\subsection{FTIR Test}

The FTIR spectra of spalted and sound wood before and after VTC treatment are shown in Figure 6.

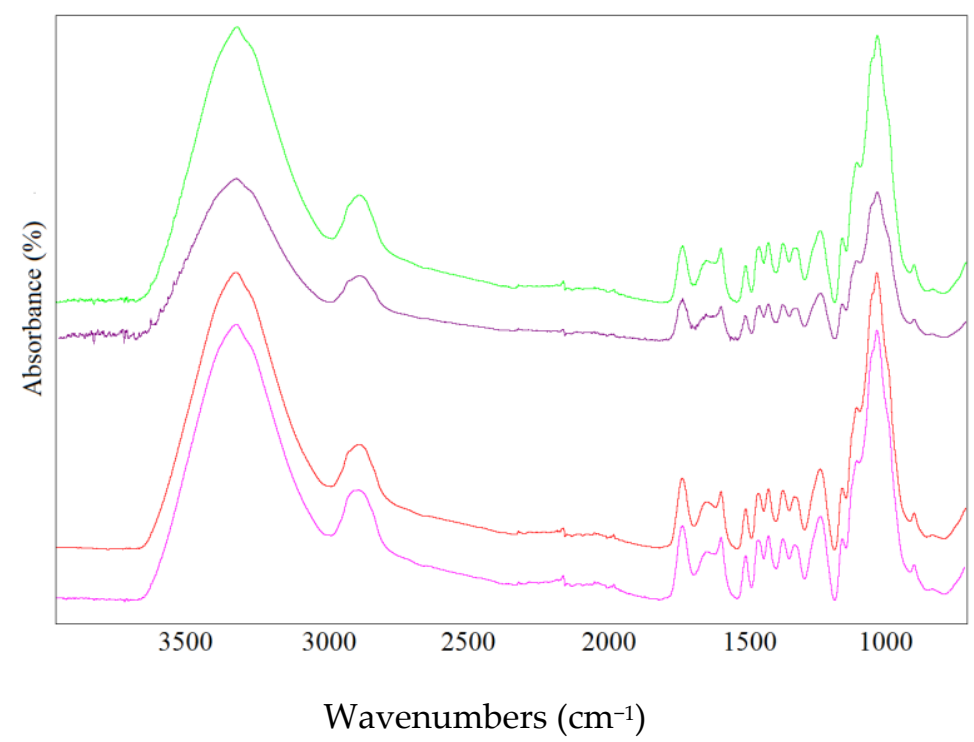

Figure 6. FTIR in the absorbance scale (\%) of spalted and sound wood before and after VTC treatment: spalted wood before (green line) and after (purple line) treatment; sound wood before (red line) and after (pink line) treatment.

The infrared spectra of the wood specimens showed that the positions of most bands and their intensities in the fingerprint region are similar with only a few slight differences. The FTIR spectra show a more expressive reduction in the wood polymers for spalted wood than for sound wood.

\section{Discussion}

\subsection{In General}

Mechanical and physical properties of wood can be changed through a variety of different treatment processes. One of these is the thermal treatment of wood, which is well known for increasing durability and stability due to chemical changes in wood components. These changes depend on the species treated and on the process conditions: temperature, time, and absence of oxygen [18]. 
High temperatures reduce the degree of polymerization of carbohydrates and form cross-linking reactions, leading to better dimensional stability and less hygroscopicity, limiting the flow of free water through the cells [19]. The reduction in hygroscopicity is due in part to the degradation of hemicellulose, which is the most hygroscopic polymer in wood [20]. In general, hemicellulose is the most sensitive component in wood with regard to heat and moisture changes, while lignin is the most stable [21].

Thermal treatments of wood can be detrimental, as long exposures to high temperatures can decrease the density and mechanical properties. For instance, Esteves et al. [22] reported that thermal treatments can cause mass loss in the wood, which is used to determine the degree or severity of a thermal treatment. Wood degradation happens between 100 and $200{ }^{\circ} \mathrm{C}$ as well as at higher temperatures [23]. Excessive high temperatures can cause wood degradation as well as discoloration on the surface of the wood [24].

\subsection{Density}

The VTC process increased the density of spalted and sound wood by $84 \%$ and $90 \%$, respectively, confirming the assumption that spalted wood can have its density increased through the VTC process. The result achieved in this study was similar to the results of other studies that used the VTC technology to increase the density and mechanical properties of low-density wood species [9,25-27]. Additionally, this study confirmed that the VTC technology was significantly effective at increasing the density of not only low-density woods but also spalted wood, something that has never been tested before.

Interestingly, the performance of the VTC treatment in spalted wood was statistically different than in sound wood. The treatment caused higher density changes in sound wood than in spalted wood. In theory, the VTC treatment should have performed equally or better in spalted wood, as its pre-treatment average density was lower than the pre-treatment average density of sound wood, 472 and $562 \mathrm{~kg} / \mathrm{m}^{3}$, respectively. This assumption was supported by a study that investigated the densification of alder, beech, birch, and pine veneers, which showed that the wood with the lowest density was the one that achieved the highest density after treatment [28].

To explain the better performance of the VTC process in sound wood than spalted wood, further analysis was conducted. As the VTC process causes mass loss (a thermal loss of water up to $100{ }^{\circ} \mathrm{C}$; after this, a percentage mass is lost very quickly due to the elimination of water and the degradation of polysaccharides [28]), the thickness of post-treated spalted wood specimens and the mass caused by the high temperature of the treatment were investigated.

Densification was controlled by thickness, so each specimen achieved the same reduced thickness inside the VTC device. When removed from the VTC device, some specimens exhibited more elastic recovery than others. Additionally, a statistical analysis using a $t$-test showed that the thickness of post-treated spalted wood specimens was not statistically significant different from the thickness of post-treated sound wood specimens $(t(28)=0.7, p=0.30)$ (the post-treated spalted and sound wood had the same volume). However, the VTC process caused significantly different mass losses in spalted and sound wood $(t(28)=6, p<0.0001)$; mass loss was higher for spalted $(2 \%)$ than for sound wood $(0.7 \%)$. Hence, after the VTC process, spalted wood specimens had lower mass weight than sound wood specimens. Due to the way in which density is calculated (mass/volume), the denominator remained constant, while the numerator was lower for spalted than for sound wood. This at least partially explains the improved performance in sound wood compared with spalted wood.

The spalted wood lost more mass than the sound wood. This can be partially explained by noting the different performances of the VTC process in spalted and sound wood, likely due to anatomical differences. It is important to point out that, to conduct this study, specimens with a high percentage of zone lines, which are most commonly formed by white rot fungi, were selected for testing. However, not only zone lines were present in the wood; white rot spalting fungi were also present in the wood specimens in varying amounts, which meant that the wood was at least partially decayed (and had a loss of lignin). 
Previous literature [28-30] states that white rot fungi cause drastic changes in the structural integrity of the wood. During the colonization of the wood by white rot fungi, the pits (openings in the cell walls of the wood) are the principal cell wall elements penetrated by the hyphae of the fungi. After the penetration, the fungi start their development in the vessels and rays of the wood, and pits are then enlarged due to enzymes secreted by the fungi. White rots may also cause tiny pockets and cavities with conical ends in the secondary cell wall. As the fungi develop in the wood, the surface of the cell walls are degraded enzymatically, leading to a gradual thinning of the cell walls from the lumens toward the middle lamella (consisted of lignin and pectin). Moreover, it has been reported that some white rot fungi species may degrade the middle lamella, which results in cell detachment. These fungi are able to completely degrade the wood, causing weight losses of about $96-97 \%$.

Since pits represent the major limiting factor in conduction of water and various solutes between adjacent cells in the wood, the enlargement of the pits and degradation of the cell walls make the wood absorb and desorb liquids faster than sound wood. Therefore, these anatomical changes in the structure of spalted wood might have helped with a higher water flow inside the wood specimens during the VTC process, causing higher mass losses in spalted wood.

\subsection{Color Test}

The results of this study indicated that spalted and sound wood specimens became darker $\left(-L^{*}\right)$ after the VTC process. This result is supported by past studies that showed an increase in dark tonality of the wood after hydrothermal treatments [22,31-34]. The color change represents the severity of the process: the higher the temperature and treatment time, the darker the color of the wood [22,35]. As expected, the specimens became darker; however, while $b^{*}$ values remained in the same range and were not significantly changed by the VTC treatment, $a^{*}$ values were significantly affected and increased. This resulted in samples with a reddish hue. This "redding" of the wood has not been reported before, although there are few studies where $L^{*} a^{*} b^{*}$ values were reported after the VTC process. Of note is a study conducted by Lesar et al. (2013) [36] that tested thermo-hydro-mechanical treatments on hybrid poplar and Douglas fir, where the results of $a^{*}$ and $b^{*}$ values remained in the same range after the treatment.

The color changes in the wood might be explained due to complex chemical changes involving degradation of cellulose and hemicelluloses, the oxidation of lignin and lignin polymerization reactions, and the presence of extractive compounds [31-33,37-41]. Temperatures ranging from 40 to $90{ }^{\circ} \mathrm{C}$ already cause chemical changes in certain extractives, and above that temperature changes occur in all components of the wood [36,42]. During hydro-thermal treatments, $\alpha$ - and $\beta$-ether bonds in lignin break, forming intermediate lignin degradation compounds, such as quinone and quinonemethide, which have strong colors [26]. In this study, the temperature used to VTC-treat the wood was $150{ }^{\circ} \mathrm{C}$. A previous study found that the splitting of $\beta$-aryl ethers caused condensation of lignin products from 100 to $120^{\circ} \mathrm{C}$, and hemolytic cleavage of phenolic $\beta$-aryl ethers around $130{ }^{\circ} \mathrm{C}$ in maple has been reported [42].

VTC-treated wood is characterized by a darker color, a smoother surface, and a high surface gloss finishing [28,43-45], and the treated spalted wood showed these traits (see Figure 7) when compared to untreated sound wood. The VTC treatment also allowed the highlighting of the aesthetical values of the spalted wood (zone lines and bleached patterns). 


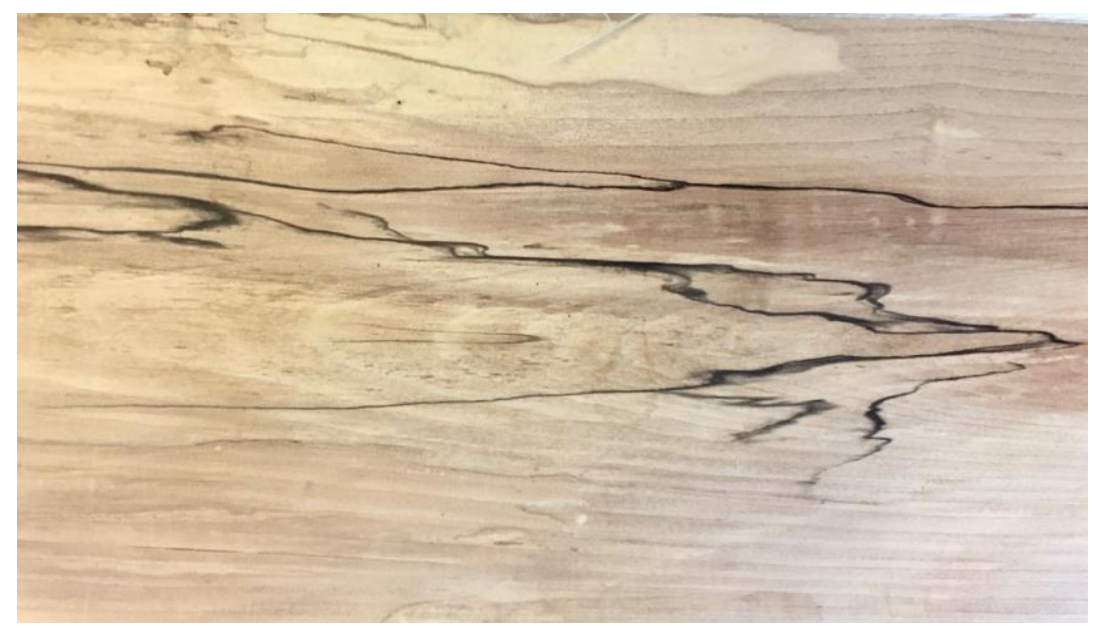

Figure 7. Sample shows a remarkable smooth surface as a result of the VTC process.

An unexpected benefit of the VTC process on spalted wood is the smooth finish it gives to the final layer-a layer that requires no additional sanding or finishing. Experts in woodturning spalted wood, such as Lindquist (1977) [2] and Robinson (2018) [8], have discussed the issues surrounding sanding spalted wood, as the heterogeneity of this material (varied density, the presence of so-called "punky" spots within the wood, and soft areas) results in an uneven surface when sanding, as the punky areas are sanded more quickly than can the sound areas. Moreover, to get past all the pecks and chips that form in the wood surface from working the brittle spalted wood, extensive sanding time is required. Therefore, skipping the sanding step of the VTC-treated spalted wood veneers does not only fix the problem of sanding spalted wood but also helps to reduce manufacturing time and costs associated with the sanding process (sanding machines, sand paper, and human labor).

\subsection{Hardness Test}

The F-test of the Brinell hardness values determined that the VTC process significantly increased the hardness of both spalted and sound wood by $209 \%$ and $105 \%$, respectively. This result confirms that spalted wood can have its hardness enhanced successfully through the VTC technology. Similar improvements in the Brinell hardness of low-density wood species caused by the VTC process have already been reported [9,12,46-52].

The statistical analysis also confirmed that, after the VTC treatment, the Brinell hardness of the spalted wood specimens was not significant different from the hardness of the sound wood specimens. In other words, the VTC technology was able to increase the hardness of spalted wood to the same as the sound wood. This result is promising, as VTC-treated spalted wood can be used for flooring applications.

\subsection{Set Recovery Test}

The results of the set recovery after the 5th cycle of soaking in water for $24 \mathrm{~h}$ and drying at $103{ }^{\circ} \mathrm{C}$ for $24 \mathrm{~h}$ were statistically significantly higher for spalted (78\%) than sound wood (71\%). Similar or even higher set recovery values have been found for high densified wood veneers and solid wood [50,53].

The almost complete set recovery of compressed wood when exposed to high levels of moisture or cycle weathering is well known [54,55], as the compression of wood makes cell walls store elastic strain energy, which is released when the wood is exposed to humidity; and the set recovery measures this release of energy [56-58]. The compression of wood forms cross-linkages in lignin and the crystalline regions of cellulose, that remain in in the compressed shape $[59,60]$. Besides the cross- linkages formation, there is also formation of hydrogen bonds between hemicelluloses and cellulose holding the cellulose microfibrils in place until they are forced to separate, due to moisture or heat contact [17]. 
As mentioned earlier, spalted wood has its anatomical structure and chemistry modified by the action of fungi. Anatomically, white rot fungi penetrate and enlarge the pits of the woods by secreting enzymes. As the fungi grow, they develop in the vessels and rays of the wood, causing the thinning of the cell walls from the lumen to toward the middle lamella. The mass loss caused by fungi is strongly related to the reduction of mechanical properties of the wood. Fungi also digest wood polymers, breaking the long chains into shorter structures. However, these new and shorter compounds formed in the wood do not have the same moisture-holding capacity, nor the same capacity to store elastic strain energy when the wood is compressed [28-30]. Therefore, the differences in the anatomical structure and chemistry of spalted wood may explain the higher set recovery percentage for spalted than for sound wood.

To be used as wood flooring, VTC-treated spalted wood has to be resistant to changes in moisture content. Therefore, the set recovery issue must be addressed not only for spalted wood but also for solid wood, wood veneers, and wood composites that will be exposed to moisture variations. Different attempts to reduce or minimize set recovery have been studied intensively $[14,17,54,61]$. One method of elimination is through further thermal and hydro-thermal modification with different temperatures and processing time. Another is thermo-hydro-mechanical modification combined with oil, post-steaming resin impregnation [48-50,53,57,62-64]. The product tested in this research was wood flooring, so further investigations into coatings for spalted wood could help to fix the set recovery issue.

\subsection{FTIR Test}

The FTIR spectra of spalted and sound wood showed that there were fewer overall functional groups in spalted wood than sound wood. The detection of chemical changes in wood polymers caused by thermal treatments using FTIR spectra has been extensively studied [65-68], so the position of the peak bands were identified based on previous studies.

Stronger absorption bands for sound wood over spalted wood found on peaks at 1031, 1235, 1505, and $1732 \mathrm{~cm}^{-1}$ were expected. The FTIR spectra confirmed the literature [27-29] that the chemistry of spalted wood is different from the chemistry of sound wood. As already mentioned, spalted wood has its compounds biodegraded by fungal enzymes. Carbohydrates are depolymerized, and lignin is oxidized, forming new compounds in the wood. Therefore, a reduction or modification of the wood polymer amount, or even the presence of different compounds (such as the melanin in zone lines), was expected, and was confirmed via FTIR.

In addition, after the VTC process, the same peaks at 1031, 1235, 1505, and $1732 \mathrm{~cm}^{-1}$ were analyzed again. A slight modification due to the treatment was shown. The absorption bands of the peaks at 1031, 1235, 1505, and $1732 \mathrm{~cm}^{-1}$ were reduced after the treatment for both spalted and sound wood, which might have happened because of the degradation of the wood polymers due to the temperature used to VTC-treat the wood specimens.

The most noticeable changes caused by the VTC treatment were seen at the peak $1031 \mathrm{~cm}^{-1}$, which indicates cellulose [69]. Previous studies have reported that the most visible decrease in the FTIR spectra on heat-treated woods was on the cellulose and hemicelluloses peaks $[36,67]$. The peak at $1235 \mathrm{~cm}^{-1}$ indicates crystallized cellulose I, showing that the crystallinity of the cellulose might be affected by the VTC treatment as well $[65,66]$. The peak at $1505 \mathrm{~cm}^{-1}$ was characteristic of lignin with aromatic skeletal vibration [67]. The peak at $1732 \mathrm{~cm}^{-1}$ was caused by carbonyl and acetyl groups that indicate hemicelluloses, specifically xylans (O-acetyl-4-Omethylglucurono-xylan) in hardwoods [70].

A closer look at peaks 1031 and $1235 \mathrm{~cm}^{-1}$ showed that the decrease in the cellulose band after the VTC process was more significant for spalted than for sound wood. This might be due to the action of fungi in the chemistry of spalted wood. White rot fungi are able to break down all three major polymers of the wood, and are capable of degrading lignin, the 3-D polymer responsible for the rigidity of the wood. The degradation and reduction in the amount of lignin in the wood due to the 
breakdown caused by fungi might have left the polysaccharides chains exposed and more vulnerable to degradation caused by heat used to VTC-treat the wood specimens.

\section{Conclusions}

Density and Brinell hardness of spalted wood were successfully increased using the VTC process. VTC-treated spalted wood veneers in this experiment experienced increases in density and hardness of approximately $84 \%$ and $209 \%$, respectively. The VTC process has the potential to give spalted wood the physical and mechanical properties required for use in flooring, opening up an entirely new market for this decorative wood. However, the use of VTC-treated wood for flooring applications is limited by its susceptibility to thickness swelling when exposed to moisture as the set recovery results showed in this study. One solution would be the application of a coating on the surface of the VTC-treated spalted wood, which, besides protecting the wood against moisture, would help the VTC-treated spalted veneers become more durable. Additional testing is still needed on spalted wood veneers to determine their resistance to impact, which is highly relevant in flooring applications.

FTIR spectrum analysis after VTC pressing revealed changes in the presence of functional groups for spalted wood and sound wood. Furthermore, the VTC process caused color changes: the color of the surface of spalted wood became darker and redder. Future research should investigate the acceptability of VTC-treated spalted wood flooring by wood flooring manufactures and by consumers. Changes and optimizations of the VTC process might be needed to adapt the production of this special wood-based composite for an industrial scale.

Author Contributions: Conceptualization, S.C.R. and F.A.K.; Methodology, F.A.K. and D.R.d.O.; Software, D.R.d.O.; Validation, S.C.R., F.A.K. and D.R.d.O.; Formal Analysis, D.R.d.O. and S.M.V.G.; Investigation, D.R.d.O and C.C.A.; Resources, S. C.R. and F.A.K.; Data Curation, D.R.d.O; Writing-Original Draft Preparation, D.R.d.O and S.M.V.G.; Writing-Review and Editing, D.R.d.O., C.C.A., S.M.V.G. and F.A.K. and S.C.R.; Supervision, S.R.; Project Administration, S.C.R. and F.A.K.

Funding: This research received no external funding.

Conflicts of Interest: The authors declare no conflict of interest.

\section{References}

1. Donovan, G.H.; Nicholls, D.L. Consumer preferences and willingness to pay for character-marked cabinets from alaska birch. For. Prod. J. 2003, 53, 27-32.

2. Lindquist, M. Spalted wood. Rare jewels from death and decay. Fine Woodwork. 1977, 7, 50-53.

3. Robinson, S.C.; Michaelsen, H.; Robinson, J.C. Spalted Wood: The History, Science and Art of a Unique Material, 1st ed.; Schiffer Publishing: Atglen, PA, USA, 2016; p. 287.

4. Robinson, S.C.; Tudor, D.; MacDonald, G.; Mansourian, Y.; Cooper, P.A. Repurposing mountain pine beetle blue wood for art through additional fungal colonization. Int. Biodeterior. Biodegrad. 2013, 85, 372-374. [CrossRef]

5. Robinson, S.C. Developing fungal pigments for "painting" vascular plants. Appl. Microbiol. Biotechnol. 2012, 93, 1389-1394. [CrossRef] [PubMed]

6. Vega Gutierrez, S.M.; Kramer, O.E.; Andersen, C.C.; Vega Gutierrez, P.T.; Robinson, S.C. A method for citizen scientists to catalogue worldwide Chlorociboria spp. Distribution. Challenges 2018, 9, 11. [CrossRef]

7. Christensen, K.W. Improving the Working Properties of Spalted Woods through Impregnation with Methyl Methacrylate; Brigham Young University, Department of Industrial Education: Provo, UT, USA, 1982.

8. Robinson, S.C.; Vega Gutierrez, S.M.; Cespedes Garcia, R.A.; Iroume, N.; Vorland, N.R.; Andersen, C.; de Oliveira Xaxa, I.D.; Kramer, O.E.; Huber, M.E. Potential for fungal dyes as colorants in oil and acrylic paints. J. Coat. Technol. Res. 2018, 15, 1-5. [CrossRef]

9. Kamke, F.A. Densified radiata pine for structural composites. Maderas. Ciencia y Tecnologia 2006, 8, 83-92.

10. Kutnar, A.; Kamke, F.A.; Nairn, J.A.; Sernek, M. Mode II fracture behavior of bonded viscoelastic thermal compressed wood. Wood Fiber Sci. 2008, 40, 362-373.

11. O'Connor, J.P. Improving Wood Strength and Stiffness through Viscoelastic Thermal Compression. Master's Thesis, Oregon State University, Corvallis, OR, USA, June 2007. 
12. Rautkari, L.; Kamke, F.A.; Hughes, M. Density profile relation to hardness of viscoelastic thermal compressed (VTC) wood composite. Wood Sci. Technol. 2011, 45, 693-705. [CrossRef]

13. Robinson, S.C.; Laks, P.E.; Richter, D.L.; Pickens, J.B. Evaluating loss of machinability in spalted sugar maple. For. Prod. J. 2007, 57, 33-37.

14. Kutnar, A.; Kamke, F.A. Compression of wood under saturated steam, superheated steam, and transient conditions at $150^{\circ} \mathrm{C}, 160{ }^{\circ} \mathrm{C}$, and $170{ }^{\circ} \mathrm{C}$. Wood Sci. Technol. 2012, 46, 73-88. [CrossRef]

15. Kutnar, A.; Humar, M.; Kamke, F.A.; Sernek, M. Fungal decay of viscoelastic thermal compressed (VTC) wood. Eur. J. Wood Wood Prod. 2011, 69, 325-328. [CrossRef]

16. BS EN 1534:2000: Wood and Parquet Flooring_Determination of Resistance to Indentation (Brinell)_Test Method; BSI Group: London, UK, 2000.

17. Laine, K.; Rautkari, L.; Hughes, M.; Kutnar, A. Reducing the set-recovery of surface densified solid scots pine wood by hydrothermal post-treatment. Eur. J. Wood Wood Prod. 2013, 71, 17-23. [CrossRef]

18. Militz, H. Thermal treatment of wood: European processes and their background. IRG/WP 2002, 2002, 02-40241.

19. Schwarze, F.W.; Spycher, M. Resistance of thermo-hydro-mechanically densified wood to colonization and degradation by brown-rot fungi. Holzforschung 2005, 59, 358-363. [CrossRef]

20. Bhuiyan, T.R.; Hirai, N.; Sobue, N. Change of crystallinity in wood cellulose by heat-treatment under dried and moist conditions. J. Wood Sci. 2000, 46, 431-436. [CrossRef]

21. Fengel, D.; Wegener, G. Wood: Chemistry Ultrastructure Reactions; Walter de Gruyter \& Co.: Berlin, Germany, 1989; pp. 319-336.

22. Esteves, B.; Marques, A.V.; Domingos, I.; Pereira, H. Heat-induced colour changes of pine (Pinus pinaster) and eucalyptus (Eucalyptus globulus) wood. Wood Sci. Technol. 2008, 42, 369-384. [CrossRef]

23. Bowyer, J.L.; Shmulski, R.; Haygreen, J.G. Forest Products and Wood Science: An Introduction, 4th ed.; Iowa State University Press: Ames, IA, USA, 2003; pp. 3-23.

24. Heger, F.; Groux, M.; Girardet, F.; Welzback, C.; Rapp, A.O.; Navi, P. Mechanical and durability performance of THM-densified wood. Proceedings of Environmental Optimization of Wood Protection Workshop, Lisboa, Portugal, 22-23 March 2004.

25. Kamke, F.A.; Rautkari, L. Modified wood veneer for structural applications. In Proceedings of the 4th International Symposium on Veneer Processing and Products (ISVPP), Espoo, Finland, 24-27 May 2009; pp. 207-212.

26. Kutnar, A.; Kamke, F.A.; Sernek, M. Density profile and morphology of viscoelastic thermal compressed wood. Wood Sci. Technol. 2009, 43, 57. [CrossRef]

27. Kutnar, A.; Kamke, F.A. The influence of heat treatment on the set recovery of compressive deformation. In Proceedings of the 1st International Conference on Processing Technologies for the Forest and Biobased Products Industries (PTF BPI), Salzburg University of Applied Sciences, Kuchl, Austria, 7-8 October 2010.

28. Bekhta, P.; Proszyk, S.; Krystofiak, T.; Sedliacik, J.; Novak, I.; Mamonova, M. Effects of short-term thermomechanical densification on the structure and properties of wood veneers. Wood Mater. Sci. Eng. 2015, 12, 40-54. [CrossRef]

29. Zabel, R.A.; Morrell, J.J. Wood Microbiology: Decay and Its Prevention; Harcourt Brace Jovanovich, Academic Press, Inc.: New York, NY, USA, 1992.

30. Hoadley, R.A. Identifying Wood: Accurate Results with Simple Tools; Tauton Press: Newtown, CT, USA, 1990.

31. Koch, G.; Puls, J.; Bauch, J. Topochemical characterisation of phenolic extractives in discoloured beechwood (Fagus sylvatica L.). Holzforschung 2003, 54, 339-345. [CrossRef]

32. Sundqvist, B.; Karlsson, O.; Westermark, U. Determination of formic-acid and acetic acid concentrations formed during hydrothermal treatment of birch wood and its relation to colour, strength and hardness. Wood Sci. Technol. 2006, 40, 549. [CrossRef]

33. Tjeerdsma, B.F.; Boonstra, M.; Tekely, P.; Militz, H. Characterisation of thermally modified wood: Molecular reasons for wood performance improvement. Holz als Roh- und Werkstoff 1998, 56, 149. [CrossRef]

34. Varga, D.; van der Zee, M.E. Influence of steaming on selected wood properties of four hardwood species. Holz als Roh- und Werkstoff 2008, 66, 11. [CrossRef]

35. Welzbacher, C.R. Tmt-interlab-test to establish suitable quality control techniques-structure and first results. Proceedings of 41st Annual Meeting of the International Research Group on Wood Protection, Biarritz, France, 9-13 May 2010. 
36. Lesar, B.; Humar, M.; Kamke, F.A.; Kutnar, A. Influence of the thermo-hydro-mechanical treatments of wood on the performance against wood-degrading fungi. Wood Sci. Technol. 2013, 47, 977-992. [CrossRef]

37. Bekhta, P.; Niemz, P. Effect of high temperature on the change in color, dimensional stability and mechanical properties of spruce wood. Holzforschung 2005, 57, 539-546. [CrossRef]

38. Curling, S.F.; Clausen, C.A.; Winandy, J.E. Relationships between mechanical properties, weight loss, and chemical composition of wood during incipient brown-rot decay. For. Prod. J. 2002, 52, 34.

39. Humar, M.; Amartey, S.A.; Pohleven, F. Influence of corn steep liquor and glucose on colonization of control and CCB $(\mathrm{Cu} / \mathrm{Cr} / \mathrm{B})$-treated wood by brown rot fungi. Waste Manag. 2006, 25, 459-469. [CrossRef]

40. Mayer, I.; Koch, G. Element content and pH value in American black cherry (Prunus serotina) with regard to colour changes during heartwood formation and hot water treatment. Wood Sci. Technol. 2007, 41, 537. [CrossRef]

41. Sundqvist, B.; Morén, T. The influence of wood polymers and extractives on wood colour induced by hydrothermal treatment. Holz als Roh- und Werkstoff 2002, 60, 375-376. [CrossRef]

42. Sundqvist, B. Colour Changes and Acid Formation in Wood during Heating. Ph.D. Thesis, Luleå University of Technology, Godkänd, Sweden, January 2004.

43. Bekhta, P.; Proszyk, S.; Krystofiak, T. Colour in short-term thermo-mechanically densified veneer of various wood species. Eur. J. Wood Wood Prod. 2014, 72, 785-797. [CrossRef]

44. Bekhta, P.; Proszyk, S.; Lis, B.; Krystofiak, T. Gloss of thermally densified alder (Alnus glutinosa Goertn.), beech (Fagus sylvatica L.), birch (Betula verrucosa Ehrh.), and pine (Pinus sylvestris L.) wood veneers. Eur. J. Wood Wood Prod. 2014, 72, 799-808. [CrossRef]

45. Diouf, P.N.; Stevanovic, T.; Cloutier, A.; Fang, C.-H.; Blanchet, P.; Koubaa, A.; Mariotti, N. Effects of thermo-hygro-mechanical densification on the surface characteristics of trembling aspen and hybrid poplar wood veneers. Appl. Surf. Sci. 2011, 257, 3558-3564. [CrossRef]

46. Arruda, L.M.; Del Menezzi, C.H.S. Effect of thermomechanical treatment on physical properties of wood veneers. Int. Wood Prod. J. 2013, 4, 217-224. [CrossRef]

47. Candan, Z.; Hiziroglu, S.; McDonald, A.G. Surface quality of thermally compressed douglas-fir veneer. Mater. Des. 2010, 31, 3574-3577. [CrossRef]

48. Fang, C.-H.; Mariotti, N.; Cloutier, A.; Koubaa, A.; Blanchet, P. Densification of wood veneers by compression combined with heat and steam. Eur. J. Wood Wood Prod. 2012, 70, 155-163. [CrossRef]

49. Kariz, M.; Kuzman, M.K.; Sernek, M.; Hughes, M.; Rautkari, L.; Kamke, F.A.; Kutnar, A. Influence of temperature of thermal treatment on surface densification of spruce. Eur. J. Wood Wood Prod. 2017, 75, 113-123. [CrossRef]

50. Rautkari, L.; Properzi, M.; Pichelin, F.; Hughes, M. Properties and set-recovery of surface densified Norway spruce and European beech. Wood Sci. Technol. 2010, 44, 679-691. [CrossRef]

51. Rautkari, L.; Laine, K.; Kutnar, A.; Medved, S.; Hughes, M. Hardness and density profile of surface densified and thermally modified scots pine in relation to degree of densification. J. Mater. Sci. 2013, 48, 2370-2375. [CrossRef]

52. Gong, M.; Lamason, C.; Li, L. Interactive effect of surface densification and post-heat-treatment on aspen wood. J. Mater. Proc. Technol. 2010, 210, 293-296. [CrossRef]

53. Antikainen, T.; Paajanen, O.; Rautkari, L.; Kutnar, A.; Kamke, F.A.; Hughes, M. Simultaneous drying and densification of silver birch (Betula pendula L.) veneers: Analysis of morphology, thickness swelling, and density profile. Wood Sci. Technol. 2014, 48, 325-336. [CrossRef]

54. Navi, P.; Heger, F. Combined densification and thermo-hydro-mechanical processing of wood. MRS Bull. 2004, 29, 332-336. [CrossRef]

55. Welzbacher, C.R.; Wehsener, J.; Rapp, A.O.; Haller, P. Thermo-mechanical densification combined with thermal modification of norway spruce (Picea abies Karst) in industrial scale-Dimensional stability and durability aspects. Holz als Roh- und Werkstoff 2008, 66, 39. [CrossRef]

56. Hsu, W.E.; Schwald, W.; Scwald, J.; Shields, J.A. Chemical and physical changes required for producing dimensionally stable wood-based composites. Wood Sci. Technol. 1988, 22, 281-289. [CrossRef]

57. Shams, M.I.; Kagemori, N.; Yano, H. Compressive deformation of wood impregnated with low molecular weight phenol formaldehyde (pf) resin iv: Species dependency. J. Wood Sci. 2006, 52, 179-183. [CrossRef]

58. Wolcott, M.P.; Shutler, E.L. Temperature and moisture influence on compression-recovery behavior of wood. Wood Fiber Sci. 2007, 35, 540-552. 
59. Bodig, J.; Jayne, B.A. Mechanics of Wood and Wood Composites; Van Nostrand Reinhold Company: New York, NY, USA, 1982.

60. Morsing, N.; Hoffmeyer, P. Densification of wood: The influence of hygrothermal treatment on compression of beech perpendicular to gain. Ph.D. Thesis, Danmarks Tekniske Universitet, Copenhagen, Denmark, 1998.

61. Navi, P.; Sandberg, D. Thermo-Hydro-Mechanical Wood Processing; EPFL Press: Boca Raton, FL, USA, 2012.

62. Inoue, M.; Norimoto, M.; Tanahashi, M.; Rowell, R.M. Steam or heat fixation of compressed wood. Wood Fiber Sci. 1993, 25, 224-235.

63. Inoue, M.; Sekino, N.; Morooka, T.; Rowell, R.M.; Norimoto, M. Fixation of compressive deformation in wood by pre-steaming. Trop. For. Sci. 2008, 20, 273-281.

64. Reynolds, M.S. Hydro-Thermal Stabilization of Wood-Based Materials. Master's Thesis, Virginia Tech, Blacksburg, VA, USA, 2004.

65. Hakkou, M.; Pétrissans, M.; Zoulalian, A.; Gérardin, P. Investigation of wood wettability changes during heat treatment on the basis of chemical analysis. Polym. Degrad. Stab. 2005, 89, 1-5. [CrossRef]

66. Hakkou, M.; Pétrissans, M.; Gérardin, P.; Zoulalian, A. Investigations of the reasons for fungal durability of heat-treated beech wood. Polym. Degrad. Stab. 2006, 91, 393-397. [CrossRef]

67. Tjeerdsma, B.F.; Militz, H. Chemical changes in hydrothermal treated wood: Ftir analysis of combined hydrothermal and dry heat-treated wood. Holz als Roh- und Werkstoff 2005, 63, 102-111. [CrossRef]

68. Yildiz, S.; Yildiz, U.C.; Tomak, E.D. The effects of natural weathering on the properties of heat-treated alder wood. BioResources 2011, 6, 2504-2521.

69. Liu, H.; Shang, J.; Chen, X.; Kamke, F.A.; Guo, K. The influence of thermal-hydro-mechanical processing on chemical characterization of tsuga heterophylla. Wood Sci. Technol. 2014, 48, 373-392. [CrossRef]

70. Ma, M.-G.; Jia, N.; Zhu, J.-F.; Li, S.-M.; Peng, F.; Sun, R.-C. Isolation and characterization of hemicelluloses extracted by hydrothermal pretreatment. Bioresour. Technol. 2012, 114, 677-683. [CrossRef] [PubMed]

(C) 2019 by the authors. Licensee MDPI, Basel, Switzerland. This article is an open access article distributed under the terms and conditions of the Creative Commons Attribution (CC BY) license (http:/ / creativecommons.org/licenses/by/4.0/). 